\title{
Effect of the increase of steroid binding plasma levels after passive immunization against testosterone on the control of luteinizing hormone (LH) secretion in ovariectomized underfed dairy heifers
}

\author{
V Lermite ${ }^{1}$, J Thimonier 2, R Dufour ${ }^{3}, \mathrm{M}$ Terqui 1 \\ 1 INRA, Station de Physiologie de la Reproduction, 37380 Nouzilly; \\ 2 École Nationale Supérieure Agronomique, Place Viala, 34060 Montpellier Cedex; \\ ${ }^{3}$ Laboratoire IFFA, Rhône-Mérieux 254, rue Marcel Mérieux, BP 700969342 Lyon Cedex, France
}

(Received 28 September 1990; accepted 12 June 1991)

\begin{abstract}
Summary - The ability of passive immunization against testosterone to increase sex steroid binding levels in plasma and thus to overcome the negative feedback of oestradiol-17ß $\left(E_{2}\right)$ on LH secretion in underfed heifers was investigated. Dairy heifers were ovariectomized and divided in 3 groups: high energy diet ( $H$ group, $n=4)$, low energy diet ( $L$ group, $n=3$ ) and low energy diet $+E_{2}$ implants (LE 2 group, $n=4$ ). Twenty-four $h$ before injection of bovine immunoglobulins, the mean concentrations of $\mathrm{LH}$ were not different between $\mathrm{H}$ and $\mathrm{L}$ groups. $\mathrm{LH}$ baseline was lower $(0.8$ vs 1.1 $\mathrm{ng} / \mathrm{ml}, P<0.03)$ and the median number of $\mathrm{LH}$ pulses was higher $(10$ vs $5, P<0.03)$ in $\mathrm{H}$ than in $\mathrm{L}$ group. $E_{2}$ markedly decreased $(P<0.01)$ the mean and basal concentrations of $\mathrm{LH}(0.27 \mathrm{ng} / \mathrm{ml})$, and number of $L H$ pulses $(0)$ in the $L E_{2}$ group $(P<0.05)$. After injection of anti-testosterone immunoglobulins in the $\mathrm{L}$ group, mean and basal LH concentrations tended to decrease. The median number of $\mathrm{LH}$ pulses in the $\mathrm{L}$ group rose 8 days after immunization ( 5 vs 7 on day -1 and day $+8, P \leq$ $0.05)$. Amplitude of pulses tended to decrease after injection $(P=0.08)$. In the $L E_{2}$ group, the mean concentration and baseline of $\mathrm{LH}$ were not affected by passive immunization against testosterone, while pulses of $\mathrm{LH}$ appeared at day +1 and rose $(P=0.07)$ at day +8 after immunization with 3.5 pulses. Thus passive immunization against testosterone increased sex steroid binding levels in plas$\mathrm{ma}$ of underfed heifers and reduced the amount of $\mathrm{E}_{2}$ and/or non-ovarian steroids available for negative feedback effects on $\mathrm{LH}$ secretion.
\end{abstract}

passive immunization / steroid / LH / underfeeding / heifers

Résumé - Effet de l'augmentation du niveau de liaison plasmatique des stéroïdes après immunisation passive contre la testostérone sur le contrôle de la sécrétion de l'hormone lutéinisante (LH) chez les génisses laitières ovariectomisées et sous-alimentées. La possibilité d'augmenter les niveaux de liaison plasmatiques des stérö̈des par l'immunisation passive contre la testostérone (IP), et donc de bloquer le rétro-contrôle négatif de l'œstradiol-17及 $\left(E_{2}\right)$ sur la sécrétion de la LH chez des génisses sous-alimentées, a été étudiée. Des génisses laitières pubères ont été ovariectomisées et réparties en 3 groupes : régime alimentaire à haut niveau énergétique (groupe $H, n=4$ ), à faible niveau énergétique (groupe $L, n=3$ ) et à faible niveau énergétique associé à des implants d' $E_{2}$ (groupe $L E_{2}, \mathrm{n}=4$ ). Vingt-quatre heures avant l'injection des immunoglobulines bovines, le niveau de base de LH était plus faible $(0,8 \mathrm{vs} 1,1 \mathrm{ng} / \mathrm{ml}, \mathrm{P}<0,03)$ et le nombre médian de 
pulses de $L H$ plus élevé (10 vs $5, \mathrm{P}<0,03$ ) pour le groupe $H$ que pour le groupe $L$. E $E_{2}$ a diminué fortement $(P<0,01)$ les concentrations moyennes et basales de $L H$ dans le groupe $L E_{2}$ et supprimé la pulsatilité de $L H(P<0,05)$. L'injection d'immunoglobulines anti-testostérone au groupe $L$ a $e u$ tendance à diminuer les concentrations moyennes et basales de $\mathrm{LH}$. Le nombre médian de pulses de $L H$ a augmenté dans le groupe $L 8$ jours après $I P$ (5 vs 7 aux jours -1 et $+8, P \leq 0,05$ ), cette augmentation s'est ensuite maintenue; l'amplitude des pulses a, semble-t-il, diminué après $I P(P=0,08)$. Dans le groupe $L E_{2}$ il n'y a pas eu, après IP, de modification des concentrations moyennes et du niveau de base de $L H$ mais des pulses de $L H$ sont apparus à $j+1$ et ont augmenté $(\mathrm{P}=0,07)$ a $j+8$ avec 3,5 pulses. En conclusion, IP a augmenté les niveaux de liaison plasmatique des stéroïdes chez les génisses sous alimentées et a réduit la quantité de $E_{2}$ etlou de stéroïdes non-ovariens disponibles pour exercer un rétro-contrôle négatif sur la sécrétion de $L H$.

immunisation passive / stéroïde / LH / sous-alimentation / génisse

\section{INTRODUCTION}

Failure of the bovine female to show ovarian activity during the breeding period is a primary cause of decreased reproductive performance in beef cattle (Wiltbank, 1970). Restricting dietary intake during late pregnancy and the beginning of lactation in cow, delays the first post-partum ovulation by reducing $\mathrm{LH}$ and $\mathrm{FSH}$ levels (Echternkamp et al, 1982; Terqui et al, 1982; Gauthier et al, 1983). Oestradiol-17 $\beta$ $\left(E_{2}\right)$ is known to suppress $\mathrm{LH}$ secretion in prepubertal (Day et al, 1984) and postpartum anoestrus bovine females (Acosta et al, 1983). Heifers that were anoestrus due to restriction of intake of dietary energy had an increased sensitivity to negative feedback of $E_{2}$, which resulted in a decreased secretion of LH (Imakawa et al, 1986). The secretion of $\mathrm{LH}$ in ovariectomized heifers maintained on nutritionally inadequate diets is more sensitive to inhibitory effects of $E_{2}$ than in the same animals fed nutritionally adequate diets (Imakawa et al, 1987). There is a sex steroidbinding-protein (SBP) in the plasma of cattle, which binds mainly $5 \alpha$-dihydrotestosterone and testosterone, but also shows some cross-reactivity with $E_{2}$ (Martin et al, 1976; Suzuki et al, 1977; Lermite and Terqui, 1991). It was recently ob- served that plasma SBP levels were decreased by underfeeding in ovariectomized heifers (Lermite and Terqui, 1991). This suggested that a decrease in sex steroid binding levels in plasma of underfed heifers may contribute to an apparent increase in sensitivity to $E_{2}$ feedback. To test this hypothesis, underfed ovariectomized heifers, with and without $E_{2}$ replacement, were passively immunized with antisera that showed cross-reactivity with $\mathrm{E}_{2}$ similar to that of SBP. An increase in LH secretion after immunization was anticipated if steroid binding levels in plasma is a contributing factor to apparent changes in feedback sensitivity.

\section{MATERIALS AND METHODS}

\section{Preparation of anti-testosterone bovine immunoglobulins}

The antiserum was raised in castrated dairy bulls (Friesian $\times$ Holstein) and in intact dairy and beef cows (Friesian $\times$ Holstein and Charolais), using a multi-intradermal injection of testosterone-3-human serum albumin conjugate and Freund's complete adjuvant. After several booster immunizations, blood was collected and serum was treated (Institut Mérieux, France): sera from the different animals were pooled and a 
gamma globulin-enriched fraction was obtained by $\left(\mathrm{NH}_{4}\right)_{2} \mathrm{SO}_{4}$ precipitation (50\% saturation). The precipitate was dissolved in a minimum of water with $\mathrm{NaCl}(5 \mathrm{~g} /)$ and glycocoll $(10 \mathrm{~g} /)$ at $\mathrm{pH} 7$. The final solution, which was concentrated by about 6 -fold, was then sterilized. Normal bovine immunoglobulins (without anti-testosterone activity) were prepared using the same procedure.

\section{Animals}

Post-pubertal dairy heifers (Friesian $x$ Holstein), 18-months old were used in this study. They averaged $415 \pm 34 \mathrm{~kg}$ body weight (mean \pm SD) at the beginning of the experiment. All heifers were weighed before the time of feeding on 2 consecutive days and at 2-week intervals throughout the experiment; the average weight of the 2 consecutive days was used to determine weight changes.

\section{Experimental design}

Heifers were assigned to either a high energy diet (10.1 Mcal net energy/animal/day, $n=4$ heifers, $\mathrm{H}$ group) or a low energy diet ( $3.7 \mathrm{Mcal}$ net energy/animal/day, $n=7$ heifers, L group). All heifers were ovariectomized 87 days after the beginning of the experimental diets. Four of the $L$ heifers received 3 silastic implants each (id $=0.335 \mathrm{~cm}$; od $=0.465 \mathrm{~cm}$; length $=7 \mathrm{~cm}$; Dow Corning, France) filled with oestradiol-17 $\beta$ (Roussel-Uclaf, France). They were inserted subcutaneously in the shoulder blade at the time of ovariectomy ( $n=4, L E_{2}$ group). The remaining heifers ( $\mathrm{L}$ group, $n=3$ and $\mathrm{H}$ group, $n=4$ ) were not implanted. By day 185 after ovariecto$m y L$ and $L E_{2}$ animals received a single subcutaneous injection of anti-testosterone bovine immunoglobulins, while $H$ group heifers were injected with normal bovine immunoglobulins.

Daily blood samples were collected throughout the experimental period to follow antitesterone immunoglobulin titres after injection. To determine secretory patterns of $\mathrm{LH}$, serial blood samples were collected by jugular venipuncture at 10-min intervals for a 6 -h period on days (D) $-1,+1,+3,+8,+20,+30$ after injection of immunoglobulins (D0); plasma was harvested and stored at $-20^{\circ} \mathrm{C}$ until assayed. $E_{2}$ concentration was determined for all the heifers in one sample of each serial blood collection.

\section{Anti-testosterone bovine immunoglobulins characterization}

Titre, specificity and affinity constant of bovine anti-testosterone immunoglobulins were measured. The titre was estimated by the addition of $0.1 \mathrm{ml}$ of diluted antiserum to $0.1 \mathrm{ml}$ of $0.1 \mathrm{M}$ phosphate gelatin assay buffer $(0.1 \%$ gelatin in phosphate buffer solution, $\mathrm{pH}=7$ ) with $0.1 \mathrm{ml}$ of a fixed mass of $\left[{ }^{3} \mathrm{H}\right]$-labeled testosterone $(180$ $\mathrm{pg},\left[1,2,6,7-{ }^{3} \mathrm{H}\right]$ testosterone, specific activity $3.25 \mathrm{TBq} / \mathrm{mmol}$; Amersham, UK). The reaction volume was then incubated overnight at $4{ }^{\circ} \mathrm{C}$. The free fraction was separated by addition of $1 \mathrm{ml}$ of a suspension in assay buffer of dextran $\mathrm{T}-70(250 \mathrm{mg} / \mathrm{l})$ and charcoal $(1 \mathrm{~g} / \mathrm{l})$ and incubated for $12 \mathrm{~min}$ at $4{ }^{\circ} \mathrm{C}$ before centrifugation (1 $500 \mathrm{~g}, 15 \mathrm{~min}$ ). The supernatant containing bound steroid was transferred into vials and radioactivity was determined using a liquid scintillation spectrometer. The titre of antiserum was defined as the amount of tritiated testosterone bound by litre of antiserum or by litre of plasma of passively immunized animals ( $\mathrm{nmol}$ testosterone bound/l). The titre of the bovine antitestosterone immunoglobulins used in this study was $14300 \mathrm{nmol}$ of testosterone bound by litre of antiserum.

The specificity of anti-testosterone bovine immunoglobulins was tested by performing crossreactivity studies with various radioinert steroids (Steraloid, USA). The percentage of crossreaction was defined by the ratio of the amount of unlabeled testosterone which gave $50 \%$ of displacement of the $\left[{ }^{3} \mathrm{H}\right]$-testosterone to the amount of the competitor steroid which gave $50 \%$ of displacement of the $\left[{ }^{3} \mathrm{H}\right]$-testosterone. Cross-reactivity was as follows: $5 \alpha$-dihydrotestosterone, $44 \%$; $5 \alpha$-androstan-3 $\alpha$, 17 $\beta$-diol, $22 \%$; androstenedione, $6 \%$; oestradiol $-17 \beta$, $0.5 \%$; progesterone, $<0.1 \%$; cortisol $<0.1 \%$. The affinity constant $\left(K_{a}\right)$ analyzed using a Scatchard plot (Scatchard, 1949) was $4.0 \pm 1.2$ $\times 10^{9} \mathrm{M}^{-1}$.

In order to assess the ability of the antitestosterone serum to modify steroid feedback in cyclic cows, $40 \mathrm{ml}$ of a first batch of antitestosterone bovine serum per cow (1004 nmol 
of bound testosterone) was injected during the luteal phase, 3 days before prostaglandin analogue injection. LH surge was suppressed in 2 out 4 treated cows, which indicated that antitestosterone serum inhibited ovulation by neutralizing the positive feedback of endogenous $E_{2}$. This was also used to define a "standard" dose for passive immunization, ie $2.6 \mathrm{nmol}$ of testosterone bound per $\mathrm{kg}$ of average body weight, which represents $69 \pm 5.8 \mathrm{ml}$ of the second batch of anti-testosterone bovine immunoglobulins injected in heifers in this study.

\section{Hormone assays}

LH concentrations were measured by a double antibody-radioimmunoassay developed by Pelletier et al (1982) in sheep and modified by Montgomery et al (1985). All samples were included in the same assay to avoid inter-assay variation. The limit of detection was $0.1 \mathrm{ng} / \mathrm{ml}$ and the intra-assay coefficient of variation was $9.4 \%$ and $11.5 \%$ for 0.4 and $4 \mathrm{ng} / \mathrm{ml}$, respectively. Serial blood samples were analyzed to determine mean and basal concentrations $(\mathrm{ng} / \mathrm{ml})$ of LH, pulsatility (pulses/6 h) and amplitude (ng/ $\mathrm{ml}$ ) of pulses of $\mathrm{LH}$, through the use of Pulsar algorithms developed by Merriam and Watchter (1982). Plasma $E_{2}$ was measured using a double antibody radioimmunoassay (Terqui, 1978) after extraction from plasma by methylenedichloride. The limit of detection was $1.25 \mathrm{pg} /$ $\mathrm{ml}$ and the intra-assay coefficient of variation was $9 \%$ for $10 \mathrm{pg} / \mathrm{ml}$.

\section{Statistical analysis}

Data for body weights, $\mathrm{LH}$ and $\mathrm{E}_{2}$ concentrations and antiserum titres were subjected to a analysis of variance (Kobilinsky and Decoux, 1986). LH pulsatility was assessed by nonparametric test (Siegal, 1956): intra-group variation of LH pulsatility was analyzed using a Wilcoxon test; inter-group variation of LH pulsatility was analyzed using a Mann-Whitney test.

\section{RESULTS}

\section{Body weight variation}

Following the initiation of feeding the 2 experimental diets, evolution of the mean body weights was different between the 2 nutritional groups of heifers $(P<0.01)$. A weight loss was observed in heifers fed the low energy diet (fig 1). After the initial body weight loss, heifers stabilized in a body weight until the beginning of the blood sampling period. At $D-1, H$ group weighed $561 \pm 84 \mathrm{~kg}$ and had gained $148 \pm 36 \mathrm{~kg}$ (36\% of initial weight, $P<0.05$ ), while $\mathrm{L}$ and $L_{2}$ groups weighed $379 \pm 32 \mathrm{~kg}$ and had lost $38 \pm 29 \mathrm{~kg}$ ( $9 \%$ of initial weight, $P<0.05)$.

\section{Immunoglobulins titre after passive immunization}

Injection of anti-testosterone bovine immunoglobulins into $L$ and $L E_{2}$ groups resulted

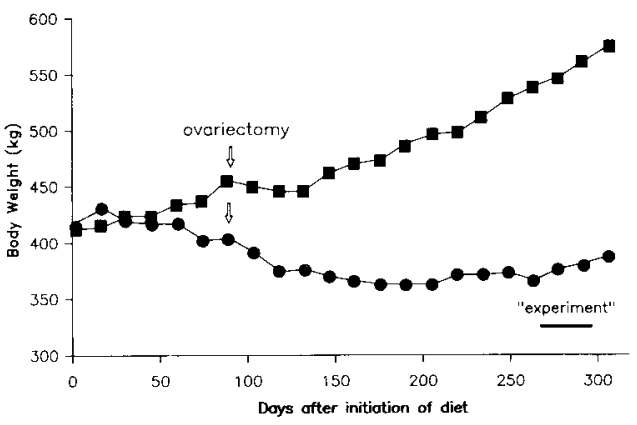

Fig 1. Mean body weights in heifers fed diets that varied in energy ( $H$ heifers: high energy $\longrightarrow-; L+L E_{2}$ heifers: low energy -0-). "experiment" : passive immunization + serial blood samples. 
in an immediate increase $(P<0.01)$ in tritiated testosterone binding in plasma, relative to $\mathrm{H}$ group (fig 2). The binding level reached a maximum 8 days after immunization ( $44 \pm 6$ vs $15 \pm 2 \mathrm{nM}$ at $D+8$ and Do, respectively) and was still elevated up to day 12. Thereafter it was followed by a low and regular decrease of the binding. Tritiated testosterone binding in plasma of the $\mathrm{H}$ group was low and constant throughout this period $(13 \pm 1.5 \mathrm{nM})$.

\section{$E_{2}$ plasma levels}

Exogenous $\mathrm{E}_{2}$ administered via the silastic implants increased $(P<0.05)$ the concentration of $E_{2}$ in jugular blood plasma of $L_{2}$ compared to $L$ and $H$ groups $(4 \pm 1.7,1 \pm$ 0.1 and $0.3 \pm 0.1 \mathrm{ng} / \mathrm{ml}$ in $L_{2}, L$ and $H$ groups, respectively). However, concentrations of $E_{2}$ were higher in $L$ than in $H$ group $(P<0.05)$. Injection of anti-testosterone immunoglobulins did not modify these concentrations.

Table I. Influence of passive immunization against testosterone on the mean concentrations of $\mathrm{LH}(\mathrm{ng} / \mathrm{ml})^{\mathrm{a}}$ in plasma of high fed heifers $(\mathrm{H}$ heifers) and underfed heifers with $E_{2}\left(L_{2}\right)$ or without $E_{2}(L)$.

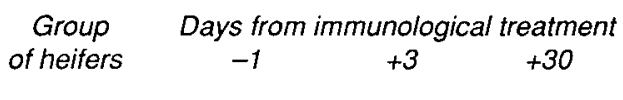

$\begin{array}{llll}\mathrm{H} \quad(n=4) & 1.0^{\mathrm{b}} \pm 0.2 & 1.1^{\mathrm{b}} \pm 0.2 & 0.8^{\mathrm{b}} \pm 0.2 \\ \mathrm{~L} \quad(n=3) & 1.3^{\mathrm{b}} \pm 0.3 & 1.2^{\mathrm{b}} \pm 0.2 & 0.9^{\mathrm{b}} \pm 0.2 \\ \mathrm{LE}_{2}(n=4) & 0.3^{\mathrm{c}} \pm 0.1 & 0.3^{\mathrm{c}} \pm 0.1 & 0.3^{\mathrm{c}} \pm 0.2\end{array}$

a mean $\pm \mathrm{SD}$. $\left({ }^{b}, \mathrm{c}\right)$ Values with different letters are significantly different $(P=0.05)$.

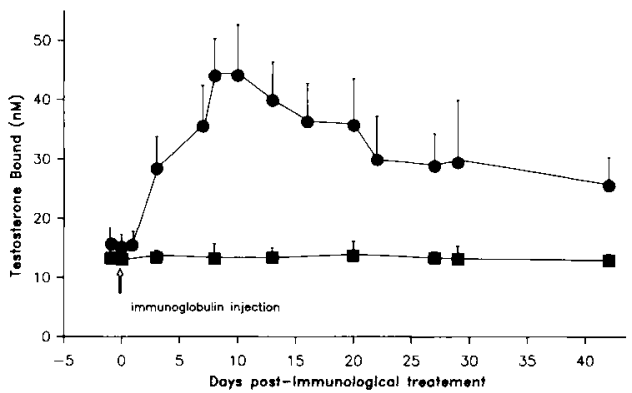

Fig 2. Tritiated testosterone bound in vitro $(\mathrm{nM}$, mean and sd) by plasma from non-immunized $(\mathrm{H}$ heifers - - ) and testosterone immunized heifers $\left(L+L E_{2}\right.$ heifers - -$)$ for a 42-d period after treatment.

\section{LH plasma levels}

At $D-1$ the mean concentrations of $\mathrm{LH}$ in plasma (table I) were not different between $H$ and $L$ groups, whereas $L H$ baseline (table II) was lower $(P<0.03)$ by $27 \%$ in $\mathrm{H}$ than in $L$ group. The median number of $\mathrm{LH}$ pulses (table III) was twice as high ( $P<$ 0.03 ) in $\mathrm{H}$ than in $\mathrm{L}$ group. Amplitude of $\mathrm{LH}$ pulses (table IV) tended to be higher in $\mathrm{L}$ than in $\mathrm{H}$ group $(P=0.07)$. $\mathrm{E}_{2}$ decreased mean concentration and baseline of $\mathrm{LH}$ in the $\mathrm{E}_{2}$ group $(P<0.01)$, and $\mathrm{LH}$ pulses were absent $(P<0.05)$.

\section{Effect of passive immunization on LH plasma levels}

After injection of non-specific immunoglobulins in $\mathrm{H}$ group, mean concentration, baseline and pulsatility of $\mathrm{LH}$ remained constant throughout the 30 days of the experiment. Injection of anti-testosterone immunoglobulins in the $L$ group tended to decrease mean concentration and baseline of $\mathrm{LH}$ on $\mathrm{D}+30(P=0.01$ and $P=0.06$ for 
mean concentration and baseline, respectively). LH pulsatility rose on $D+8$ with the median number of pulses being higher ( $P$ $\leq 0.05$ ) than on $D-1$. This increase was sustained up to $\mathrm{D}+30$. Amplitude of $\mathrm{LH}$ pulses tended to decreased after passive immunization on $\mathrm{D}+20(P=0.08)$. In the

Table 11. Influence of passive immunization against testosterone on the basal concentration of $\mathrm{LH}(\mathrm{ng} / \mathrm{ml})^{\mathrm{a}}$ in plasma of high fed heifers $(H)$ and underfed heifers with $E_{2}\left(L E_{2}\right)$ or without $E_{2}$ (L).

\begin{tabular}{cccc}
\hline Group & & & \\
of heifers & -3 & +3 & +30 \\
\hline
\end{tabular}

$\mathrm{H} \quad(n=4) \quad 0.8^{\mathrm{b}} \pm 0.1 \quad 0.8^{\mathrm{b}} \pm 0.1 \quad 0.6^{\mathrm{bc}} \pm 0.1$

ᄂ $\quad(n=3) \quad 1.1^{c} \pm 0.2 \quad 1.0^{c} \pm 0.1 \quad 0.7^{c} \pm 0.2$

$L E_{2}(n=4) \quad 0.3^{d} \pm 0.1 \quad 0.3^{d} \pm 0.1 \quad 0.3^{d} \pm 0.2$

a mean $\pm S D$. $\left({ }^{b}, c, d\right)$ Values with no common letters are significantly different $(P<0.05)$.
$\mathrm{LE}_{2}$ group the low baseline and mean concentrations of plasma $\mathrm{LH}$ were not affected by passive immunization against testosterone, but LH pulsatility appeared on $D+1$ as pulses of low amplitude and this pulsatility tended to rise on $\mathrm{D}+8(P=0.07)$. The median number of $\mathrm{LH}$ pulses decreased thereafter related to decrease in antibody titres.

\section{DISCUSSION AND CONCLUSION}

The injection of anti-testosterone immunoglobulins increased testosterone binding levels in plasma of underfed ovariectomized heifers. It was recently observed that plasma SBP binding capacity was decreased by underfeeding in ovariectomized heifers (Lermite and Terqui, 1991). The levels of binding sites in immunized underfed heifers was $29 \mathrm{nM}$ due to antitestosterone immunoglobulins 8 days after injection, plus $27 \mathrm{nM}$ of binding sites due to SBP (Lermite and Terqui, 1991). The total was close to $40 \mathrm{nM}$ of SBP binding sites found in high fed heifers (Lermite and Terqui, 1991). Passive immunization would compensate the lack of SBP binding capacity.

Table III. Influence of passive immunization against testosterone on the number of LH pulsesa in plasma of ovariectomized high fed heifers $(H)$ and underfed heifers with $E_{2}\left(L E_{2}\right.$ heifers) or without $E_{2}(L)$.

\begin{tabular}{cccccccc}
\hline & \multicolumn{7}{c}{ Days form immunological treatment } \\
Group of heifers & -1 & $+1^{2}$ & +3 & +8 & +20 & +30 \\
\hline $\mathrm{H} \quad(n=4)$ & $10^{\mathrm{b}}$ & $10^{\mathrm{b}}$ & $10.5^{\mathrm{b}}$ & $10^{\mathrm{b}}$ & $10.5^{\mathrm{b}}$ & $10.5^{\mathrm{b}}$ \\
$\mathrm{L} \quad(n=3)$ & $5^{\mathrm{c}}$ & $5^{\mathrm{c}}$ & $5^{\mathrm{c}}$ & $7^{\mathrm{e}}$ & $7^{\mathrm{c}}$ & $8^{\mathrm{e}}$ \\
$\mathrm{LE}_{2}(n=4)$ & $0^{\mathrm{d}}$ & $1^{\mathrm{d}}$ & $2.5^{\mathrm{d}}$ & $3.5^{\mathrm{d}}$ & $1^{\mathrm{d}}$ & $0^{\mathrm{d}}$ \\
\hline
\end{tabular}

a Median number of pulses detected per $6 \mathrm{~h}$ of blood serial collection. (b.c, d, e) Values with different letters are significantly different $(P<0.05)$. 
Table IV. Influence of passive immunization against testosterone on the amplitude of LH pulses (ng/ $m \mathrm{~m})^{a}$ in plasma of ovariectomized high fed heifers $(H)$ and underfed heifers with $E_{2}$ (LE $E_{2}$ or without $E_{2}$ (L).

\begin{tabular}{lllllll}
\hline & \multicolumn{7}{c}{ Days from immunological treatment } \\
Group of heifers & -1 & +1 & +3 & +8 & +20 & +30 \\
\hline$H \quad(n=4)$ & $0.5^{b} \pm 0.2$ & $0.6^{b} \pm 0.3$ & $0.8^{b} \pm 0.2$ & $0.5^{b} \pm 0.1$ & $0.6^{b} \pm 0.1$ & $0.5^{b} \pm 0.2$ \\
$L \quad(n=3)$ & $1.3^{b} \pm 0.7$ & $0.9^{b} \pm 0.8$ & $0.8^{b} \pm 0.5$ & $0.6^{b} \pm 0.1$ & $0.4^{b} \pm 0.1$ & $0.6^{b} \pm 0.1$ \\
$L_{2}(n=4)$ & & $0.2^{c} \pm 0.02$ & $0.1^{c} \pm 0.02$ & $0.2^{c} \pm 0.04$ \\
$0.2^{c} \pm 0.02$ & & & & & & \\
\hline
\end{tabular}

a Mean $\pm \mathrm{SD}$. ( ${ }^{\text {b. c })}$ Values with different letters are significantly different $(P<0.05)$.

Before immunization, number of $\mathrm{LH}$ pulses was lower in the $L$ than in the $H$ group. These data agree with the observations of Imakawa et al (1987). This decrease was independent of ovarian steroids. The increase in amplitude of pulses of $\mathrm{LH}$ in the $\mathrm{L}$ group may have resulted from the decrease in pulse number as a longer period would have resulted between pulses allowing the pituitary to build up stores of LH. Nevertheless, pulsatility of $\mathrm{LH}$ in L group is similar to that found in the early luteal phase of cyclic cows (Rahe et al, 1980; Schallenberger and Walter, 1985). Thus the pituitary in heifers fed the diet limited in energy is able to secrete large amounts of LH. The pituitary of nutritionally induced anoestrous heifers has the ability to secrete LH in large amounts following gonadal removal (Imakawa et al, 1986).

$E_{2}$ implants produced physiological concentrations of $E_{2}$, in the underfed ovariectomized heifers, which were comparable with those of intact normal fed heifers prior to oestrus (Thibier and Saumande, 1975). Baseline, mean concentration and pulsatility of $L H$ in $L E_{2}$ group were strongly de- pressed by $E_{2}$, which is in accordance with the results of Imakawa et al (1987).

The rise of $\mathrm{LH}$ pulsatility in $\mathrm{L}$ and $\mathrm{LE}_{2}$ heifers after anti-testosterone immunoglobulin injection was consistent with results of other studies which have demonstrated that in ewes (Martensz et al, 1979; Martensz and Scaramuzzi, 1979; Webb et al, 1984; Thomas et al, 1987) and in cows (Campbell et al, 1985, Chang, 1987; Price et al, 1987; D'Occhio et al, 1988) immunized either against oestrogen, androgen or progestagen, the pituitary secreted more LH. These results demonstrate that high antibody specificity is not important to the physiological response, and support the idea that immunization against steroid results in a reduced concentration of biologically active steroid and decreased negative feedback leading to an increase in $\mathrm{LH}$ levels. The present findings of increased pulsatility of $\mathrm{LH}$ in immunized underfed heifers indicate that the testosterone antibodies could decrease negative feedback by cross-reacting with and neutralizing circulating $E_{2}$ in $L_{2}$ group, or neutralizing non-ovarian steroids in the $\mathrm{L}$ group. In the $L$ groups, these steroids may 
come from a change in peripheral metabolism, and/or an increase of secretion by the adrenal. But most of the published works did not show any significant change of plasma cortisol after a long-term restriction in energy or protein in cattle (Anderson et al, 1988; Schrick et al, 1990). Moreover bovine adrenal can produce a lot of steroids (Dorfman and Ungar, 1965) and qualitative changes in adrenal secretion are possible.

In conclusion, passive immunization against testosterone increased sex steroid-binding levels in peripheral plasma and presumably reduced the amount of steroids (ovarian or non-ovarian) available for negative feedback effect on $\mathrm{LH}$ secretion. Thus the decrease of SBP binding capacity may contribute to the increase of steroid negative feedback on $\mathrm{LH}$ secretion in underfed cattle.

\section{ACKNOWLEDGMENTS}

$\checkmark$ Lermite was recipient of a Rhône-Mérieux Doctoral Fellowship. The authors thank $D$ André and his staff for help in LH and oestradiol-173 radioimmunoassay, $L$ Delaby for calculation of experimental diets, JC Thierry for his advice in making oestradiol implants, $\mathrm{JL}$ Touze and $\mathrm{J}$ Musset for management of the experimental animals.

\section{REFERENCES}

Acosta B, Tarnavsky GK, Platt TE, Hamernik DL, Brown JL, Schoenemann HM, Reeves JJ (1983) Nursing enhances the negative effect of estrogen on $\mathrm{LH}$ release in the cow. $J$ Anim Sci 57, 1530-1535

Anderson PT, Bergen WG, Merkel RA, Enright WJ, Zinn SA, Refsal KR, Hawkins DF. (1988) The relationship between composition of gain and circulating hormones in growing beef bulls fed three dietary crude protein levels. J Anim Sci 66, 3059-3067
Campbell BA, Scaramuzzi RJ, Avenell J, Hoskinson RM, Evans G (1985) L.H levels in the androgen-immune cow. Proc Ann Meet Endocr Soc Aust 28, abstr 114

Chang C, Roberts AJ, Reeves JJ (1987) Increased luteinizing hormone secretion and ovarian function in heifers actively immunized against estrogen, and progesterone. J Anim Sci $65,771-776$

D'Occhio MJ, Gifford DR, Hoskinson RM, Weatherly T, Setchell BP (1988) Gonadotrophin secretion and ovarian responses in prepubertal heifers acively immunized against androstenedione and oestradiol-17 $\beta$. J Reprod Fertil 83, 159-168

Day ML, Imakawa K, Garcia-Winder M, Zalesky DD, Schanbacher BD, Kittok RJ, Kinder JE (1984) Endocrine mechanisms of puberty in heifers: estradiol negative feedback regulation of luteinizing hormone secretion. Biol Reprod 31, 332-341

Dorfman RI, Ungar F (1965) Metabolism of Steroid Hormones. Academic Press, NY, 716 pp

Echternkamp SE, Ferrell CL, Rone JD (1982) Influence of pre- and post-partum nutrition on LH secretion in suckled post-partum beef heifers. Theriogenology 18, 283-295

Gauthier D, Terqui M, Mauléon P (1983) Influence of nutrition on pre-partum plasma levels of progesterone and total oestrogens and post-partum plasma levels of luteinizing hormone and follicle stimulating hormone in suckling cows. Anim Prod 37, 89-96

Imakawa K, Day ML, Garcia-Winder M, Zalesky DD, Kittock RJ, Schanbacher BD, Kinder JE (1986) Endocrine changes during restoration of estrous cycles following induction of anestrus by restricted nutrient intake in beef heifers. J Anim Sci 63, 565-571

Imakawa K, Day ML, Zalesky DD, Clutter A, Kittock RJ, Kinder JE (1987) Effects of 17ßestradiol and diets varying in energy on secretion of luteinizing hormone in beef heifers. $J$ Anim Sci 64, 805-815

Kobilinsky A, Decoux G (1986) Modli, un programme d'analyse de variance et de covariance. In: MODULAD, Une Bibliothèque Fortran 77 pour l'Analyse des Données. INRIA, Paris

Lermite V, Terqui M (1991) Plasma sex steroidbinding protein in mature heifers: effects of 
reproductive status, nutritional level, and porcine growth hormone, and oestradiol-17 $\beta$ treatments. Biol Reprod 44, 864-870

Martensz ND, Scaramuzzi RJ (1979) Plasma concentrations of luteinizing hormone, follicle-stimulating hormone and progesterone during the breeding season in ewes immunized against androstenedione or testosterone. J Endocrinol 81, 249-259

Martenzs ND, Scaramuzzi RJ, Van Look PFA (1979) Plasma concentrations of luteinizing hormone and follicle-stimulating hormone during anoestrus in ewes actively immunized against oestradiol-17ß, oestrone or testosterone. J Endocrinol 81, 261-269

Martin B, Fouchet C, Thibier M (1976) Steroidprotein interaction in bovine plasma. $J$ Reprod Fertil 46, 143-149

Merriam GR, Watchter KW (1982) Algorithms for the study of episodic hormone secretion. $A m$ J Physiol 243, 310-318

Montgomery GW, Martin GB, Pelletier J (1985) Changes in pulsatile $\mathrm{LH}$ secretion after ovariectomy in lle-de France ewe in two seasons. J Reprod Fertil 73, 173-183

Pelletier J, Garnier DH, de Reviers MM, Terqui $M$, Ortavant $R$ (1982) Seasonal variation in $\mathrm{LH}$ and testosterone release in rams of two breeds. J Reprod Fertil 64, 341-346

Price CA, Morris BA, Webb R (1987) Reproductive and endocrine effects of active immunization against a testosterone conjugate in the heifers. J Reprod Fertil 81, 149-160

Rahe $\mathrm{CH}$, Owens RE, Fleeger JL, Newton HJ, Harms PG (1980) Pattern of plasma luteinizing hormone in the cyclic cow: dependence upon the period of the cycle. Endocrinolgy $107,498-503$

Scatchard $G$ (1949) The attraction of proteins for small molecules and ions. Ann NY Acad Sci 51, 660-672

Schallenberger E, Walter DL (1985) Endocrine mechanisms contributing to post-partum anoestrus in dairy and beef cattle. $1 \mathrm{~m}$ : Current Topics in Veterinary Medicine and Animal Science. Endocrine Causes of Seasonal and
Lactational Anoestrus in Farm Animals (Ellendorff F, Elsaesser F, eds) Martinus Nijhoff, Dordrecht 31, 206-220

Schrick FN, Spitzer JC, Jenkins TC, Henricks DM, Althen TG (1990) Effect of dietary energy restriction on metabolic and endocrine responses during the estrous cycle of the suckled beef cow. J Anim Sci 68, 3313-3321

Siegel $S$ (1956) Non Parametric Statistics for the Behavioral Sciences. McGraw-Hill, NY, $312 \mathrm{pp}$

Suzuki Y, Itagaki E, Mori H, Hosoya T (1977) Isolation of testosterone-binding globulin from bovine serum by affinity chromatography and its molecular characterisation. J Biochem $81,1721-1731$

Terqui M (1978) Contribution à l'étude des oestrogènes chez la brebis et la truie. Thèse de Doctorat d'État ès Sciences Naturelles Univ Paris VI

Terqui M, Chupin D, Gauthier D, Perez N, Pelot $J$, Mauléon P (1982) Influence of management and nutrition on post-partum endocrine function and ovarian activity in cows. In: Current Topics in Veterinary Medicine and Animal Science. Factors Influencing Fertility in Postpartum Cows (Karg H, Schallenberger $\mathrm{E}$, eds) Martinus Nijhoff, Dordrecht, 20, 384-408

Thibier M, Saumande $J$ (1975) Oestradiol-17ß, progesterone and $17 \alpha$-hydroxyprogesterone concentrations in jugular venous plasma in cows prior to and during oestrus. J Steroid Biochem 6, 1433-1437

Thomas GB, Oldham CM, Hoskinson RM, Scaramuzzi RJ, Martin GB (1987) Effect of immunization against progesterone on oestrus, cycle length, ovulation rate, luteal regression and $\mathrm{LH}$ secretion in the ewe. Aust $J$ Biol Sci 40, 307-313

Webb R, Land RB, Pathiraja N (1984) Passive immunization against steroid hormones in the female. In: Immunological Aspects of Reproduction in Mammals (Grigthon DB, ed) Butterworths, London, 475-499

Wiltbank JN (1970) Research needs in beef cattle reproduction. J Anim Sci 31, 755-762 